\title{
UPAYA PENINGKATAN KETERAMPILAN DAN PRESTASI BELAJAR SISWA MELALUI PEMBELAJARAN CONTEXTUAL APPROACH PADA PELAJARAN BAHASA INGGRIS DI SMAN 2 KOTA JAMBI
}

\author{
WIDIANTI \\ SMA Negeri 2 Kota Jambi Provinsi Jambi \\ Email : widiantiiidiann@gmail.com
}

\begin{abstract}
ABSTRAK
Penelitian ini bertujuan untuk meningkatkan keterampilan dan prestasi belajar siswa pada pelajaran Bahasa inggris di kelas XII IPA 6 SMANegeri 2 Kota Jambi melalui pembelajaran Contextual Approach. Penelitian ini menggunakan desain penelitian tindakan kelas(PTK) yang memiliki 4 tahapan perencanaan, pelaksanaan, observasi, dan refleksi.Penelitian ini dilaksanakan dalam 2 (dua) siklus dan setiap siklus dilakukan dalam dua pertemuan. Hasil analisis menunjukkan adanya peningkatan keterampilan dan prestasi belajar siswa. Penilaian hasil observasi keterampilansiswa meningkat dimana pada kondisi awal 14 siswa atau 43,75\% meningkat menjadi 25 siswa atau 78,13\% pada siklus I dan pada siklus IImeningkat menjadi $100 \%$. Sedangkan prestasi belajar siswa menunjukkan peningkatan dari nilai rata-rata kondisi awal sebesar 66,25 pada siklus I nilai rata-rata yang diperoleh siswa adalah 72,50 dan pada siklus II rata-rata nilai yang diperoleh siswa adalah 78,13 dengan ketuntasan belajar dari 16 siswa atau 50,00\% meningkat menjadi 26 siswa atau 81,25\% dan 93,75\% atau 30 siswa pada siklus terakhir.
\end{abstract}

Kata Kunci:keterampilan siswa, prestasi belajar siswa, contextual approach, bahasa inggris.

\section{PENDAHULUAN}

Proses pembelajaran dalam kurikulum 2013 diselenggarakan secara interaktif, inspiratif, menyenangkan, menantang, memotivasi siswa untuk berpartisipasi aktif, serta memberikan ruang yan cukup bagi prakarsa, kreativitas, dan kemandirian sesuai dengan bakat, minat, dan perkembangan fisik serta psikologis siswa. Begitu juga pada Pelaksanaan pembelajaran kurikulum 2013 mengamanatkan penggunaan pendekatan pembelajaran, baik itu bersifat ilmiah (Scientific) maupun bersifat sesuai situasi dan kondisi (Contextual).

Pendidikan memiliki peran strategis dalam membentuk karakter manusia yang memiliki kualitas unggul. Undang-Undang Sistem Pendidikan Nasional, mengamanatkan bahwa pendidikan nasional memiliki fungsi untuk mengembangkan keterampilan/kemampuan warga negara sehingga tercipta peradaban bangsa yang bermartabat sebagai upaya mencerdaskan kehidupan bangsa. Karakter manusia Indonesia yang diharapkan menurut undang-undang tersebut adalah manusia yang memiliki keimanan dan ketakwaan, kepribadian mulia, sehat jasmani dan rohani, berwawasan luas, kreativitas, kemandirian, serta memiliki tanggung jawab. Usaha yang dapat dilakukan dalam pembentukan karakter yaitu melalui peningkatan kualitas pendidikan.Peran para pendidik atau guru dalam rangka meningkatkan kualitas pendidikan, diantaranya merancang pembelajaran di dalam kelas agar siswa mendapatkan pembelajaran yang bermakna dan dirancang melalui suatu kurikulum pendidikan. Dalam hal ini pemerintah telah menetapkan suatu standar kompetensi lulusan yang harus dimiliki oleh siswa yang telah menyelesaikan pendidikannya. Kompetensi tersebut disesuaikan dengan kebutuhan abad XXI, diantara kompetensi yang diperlukan tersebut yaitu mencakup pengetahuan, sikap dan keterampilan (Zakiah, dkk, 2019).

Pembelajaran yang efektif dapat diwujudkan, salah satunya melalui perancangan rencana pembelajaran yang dituangkan dalam rencana pelaksanaan pembelajaran (RPP) dengan pemilihan model pembelajaran. Dalam hal ini, diperlukan kemampuan guru untuk memilih dan menggunakan model pembelajaran dengan memperhatikan karakteristik materi pelajaran, ketersediaan media pembelajaran, perkembangan mental dan fisik siswa (Lahir, dkk, 2017).Pembelajaran yang mengkoneksikan antara materi pelajaran dengan konteks kehidupan 
sehari-hari dapat memberikan siswa banyak pengalaman dalam menafsirkan masalah dan mungkin pula menumbuhkan ide-ide yang bervariasi dalam menyelesaikan permasalahan (Silver, 1997). Proses pembelajaran seperti ini akan membiasakan siswa untuk merencanakan kegiatan pemecahan masalah, menyelesaikan/melakukan perhitungan, melakukan monitoring terhadap proses pemecahan masalah, dan mengevaluasi terhadap hasil yang telah diperoleh. Adapun salah satu pendekatan model pembelajaran yang tepat yang dapat digunakan oleh guru yaitu model pendekatan yang sesuai dengan situasi dan kondisi yang dialami siswa yang lebih dikenal dengan pembelajaran Contextual Approach (pendekatan kontekstual).

Pendekatan kontekstual adalah suatu konsep belajar di mana guru menghadirkan situasi dunia nyata ke dalam kelas dan mendorong siswa membuat hubungan antara pengetahuan yang dimiliki dengan penerapannya dalam kehidupan mereka sebagai anggota keluarga dan masyarakat (Nurhadi, dkk, 2004).Adapun Pendekatan kontekstual merupakan pendekatan pembelajaran yang menghubungkan materi pembelajaran dengan konteks kehidupan seharihari baik dalam lingkungan keluarga, masyarakat, alam sekitar dan dunia kerja, sehingga siswa mampu memiliki kemampuan untuk membuat koneksi antara pengetahuan yang diperolehnya dengan aplikasinya dalam kehidupan sehari-hari (Hidayat, 2012). Oleh karena itu, siswa perlu memahami tentang arti belajar, manfaat belajar, dan bagaimana mencapainya. Sehingga siswa akan mengerti tentang kegunaan materi pembelajaran dengan kehidupannya (Zulela, 2014).Dari pengertian tersebut yang dimaksud dengan pendekatan kontekstual dalam penelitian ini adalah suatu proses kegiatan pembelajaran di kelas, dengan menggunakan media-media konkret yang ada dekat dilingkungan siswa, yang nantinya mempermudah guru di dalam menyampaikan materi pembelajaran kepada siswa. Media konkret dalam penelitian ini dapat diartikan sebagai berwujud, tampak, nyata, benar-benar ada yang bisa siswa perhatikan dengan menggunakan alat indra dan siswa tidak menghayal dengan apa yang dipelajarinya. Pembelajaran akan menjadi menarik dan menyenangkan, karena guru menerapkan pendekatan kontekstual dengan menghadirkan media konkret yang ada di sekitar lingkungan siswa, khususnya pada materi pembelajaran Bahasa inggris (Suarjana, 2017).

Berbagai penelitian yang telah berhasil menggunakan pendekatan kontekstual, diantaranya Zakiah (2017) mengungkapkan bahwa penggunaan masalah kontekstual dalam kehidupan sehari-hari dapat membantu siswa dalam memahami materi. Hasil penelitian Zakiah dan Sunaryo (2017) melaporkan bahwa pendekatan kontekstual dengan memperhatikan gaya kognitif siswa mampu meningkatkan kemampuan metakogitif dan self awareness siswa. Selanjutnya hasil penelitian Fatimah dan Zakiah (2018) bahwa penerapan pembelajaran menggunakan pendekatan kontekstual melalui model pembelajaran scaffolding dapat meningkatkan kemampuan matematis siswa yaitu berpikir kritis matematik siswa.

Wahyuningtyas, dkk (2018) menyatakan bahwa pembelajaran kontekstual adalah sistem pembelajaran yang cocok dengan otak untuk menghasilkan makna dengan menghubungkan konten akademik dengan konteks kehidupan sehari-hari siswa. Melalui model pembelajaran kontekstual, pengajaran tidak hanya mentransformasi pengetahuan dari seorang guru ke siswa dengan menhafal sejumlah konsep yang sepertinya terlepas dari kehidupan nyata, tetapi lebih menekankan pada memfalisitasi siswa mencari kemampuan untuk hidup (keterampilan hidup) pada apa yang mereka pelajari (Suatika \& Rahmawati, 2019). Ardiyanto (2013) juga menekankan bahwa, melalui pendekatan kontekstual, siswa diharapkan belajar melalui 'mengalami', dan bukan 'menghafal'. Pendekatan kontekstual dapat menciptakan pembelajaran yang menyenangkan dan diinginkan oleh siswa. Pada kelas kontekstual, guru tugasnya adalah membantu siswa mencapai tujuan mereka.

Pendekatan kontekstual yang menekankan pada keaktifan siswa dalam belajar, seperti menemukan materi yangdipelajari dan menghubungkannya dengan situasi kehidupan nyata, maka siswa dapat lebih menguasaimateri pelajaran. Tingkat penguasaan siswa terhadap materi pelajaran akan mempengaruhi hasil belajarnya setelah melalui proses evaluasi berupapelajaran bahasa Inggris, dan keaktifannya dalam kegiatan pembelajaran bahasa Inggris (Fajar, 2014). 
Bahasa Inggris sebagai salah satu mata pelajaran dalam satuan pendidikan di SMA yang dikembangkan dalam rangka membangun sikap, pengetahuan, dan keterampilan berkomunikasi siswa melalui pengalaman pembelajaran yang berbentuk beragam kegiatan berkomunikasi aktif, baik melalui kegiatan berbahasa Inggris yang bersifat reseptif maupun produktif. Hanya dengan terlibat aktif dalam kegiatan berkomunikasi, siswa dapat membangun sikap, pengetahuan, dan keterampilan berkomunikasi (Sukra, 2016).Kenyataan di atas mengharuskan pembelajaran Bahasa Inggris dilakukan secara intensif. Namun ada kesan yang berkembang di masyarakat bahwa mata pelajaran Bahasa Inggris merupakan mata pelajaran yang sangat susah dan momok bagi siswa sehingga pengetahuan belajar siswa terhadap pelajaran bahasa Inggris tergolong rendah.

Berdasarkan hasil tes evaluasi belajar Bahasa Inggris yang dilaksanakan di kelas XII IPA 6 SMA Negeri 2 Kota Jambi diperoleh diskripsi data tes studi awal bahwa prestasi belajar siswa masih rendah, yang terlihat dari belum tercapainya ketuntasan individu dan ketuntasan klasikal dalam pembelajaran seperti yang diharapkan. Dari 32 orang siswa kelas XII IPA 6 SMAN 2 Kota Jambi sebanyak 15 orang siswa atau sebesar 50,00\% memperoleh nilai di bawah KKM, dan hanya sebanyak 17 orang siswa atau sebesar 50,00\% saja siswa yang memperoleh nilai $\geq$ KKM 75 dan pencapaian ketuntasan tersebut masih berada di bawah hasil yang diharapkan yaitu lebih dari $85 \%$ siswa yang mencapai ketuntasan. dengan perolehan nilai ratarata secara klasikal mencapai angka 66,25. Hal ini disebabkan karena siswa kurang mampu mengaitkan antara materi yang diajarkan dengan situasi dunia nyata siswa atau dalam kehidupan sehari-hari. Selain itu, juga dikarenakan penyajian materi Bahasa Inggris yang dirasakan siswa masih monoton dan membosankan sehingga siswa kurang tertarik belajar Bahasa Inggris.Kesadaran tentang perlunya penerapan pendekatan kontekstual dalam pembelajaran, didasarkan pada kenyataan bahwa sebagian besar siswa masih belum mampu mengaitkan antara apa yang mereka pelajari dengan bagaimana pemanfaatannya dalam kehidupan nyata mereka sehari-hari. Hal ini disebabkan pemahaman konsep akademik yang mereka peroleh hanyalah merupakan sesuatu yang abstrak, belum menyentuh aspek praktis kehidupan mereka, baik di lingkungan kerja maupun di masyarakat (Parhan, dkk. 2019).

Sebagai upaya lebih meningkatkan kemampuan belajar siswa, khususnya penguasaan bahasa Inggris, maka proses pembelajaran seharusnya lebih menekankan keaktifan siswa dengan menerapkan pendekatan yang relevan. Pendekatan yang dimaksud adalah pendekatan kontekstual dengan tujuan agar siswa terlibat secara aktif mengikuti pelajaran agar dapat meningkatkan penguasaan bahasa Inggris.

Berdasarkan permasalahan di atas, peneliti tertarik untuk melakukan penelitian dalam bentuk penelitian tindakan kelas (PTK) yang berjudul "Upaya Peningkatan Keterampilan dan Prestasi Belajar Siswa Melalui Pembelajaran Contextual Approach Pada Pelajaran Bahasa Inggris di SMAN 2 Kota Jambi”.

\section{METODE PENELITIAN}

Penelitian Tindakan Kelas ini dilaksanakan di kelas XII IPA 6 SMA Negeri 2 Kota Jambi yang berlokasi di Jl. Pangeran Antasari, Talang Banjar, Kec. Jambi Timur, Kota Jambi, yang merupakan sekolah dimana peneliti bertugas sebagai guru mata pelajaran bahasa Inggris. Waktu Pelaksana PTK dari bulan September sampai dengan Oktober 2019 dengan jumlah subjek penelitian siswa sebanyak 32 siswa terdiri dari 15 siswa perempuan dan 17 siswa lakilaki.Prosedur kegiatan dalam penelitian tindakan kelas (PTK) dilaksanakan dalam 2 (dua) siklus. Masing-masing silkus dilaksanakan dalam 4 (empat) tahap, yaitu perencanaan, implementasi, observasi dan refleksi. (Suyitno, 2006: 3). Prosedurkegiatan tersebut secara garis besar dapat dijelaskan pada bagan di bawah ini. 


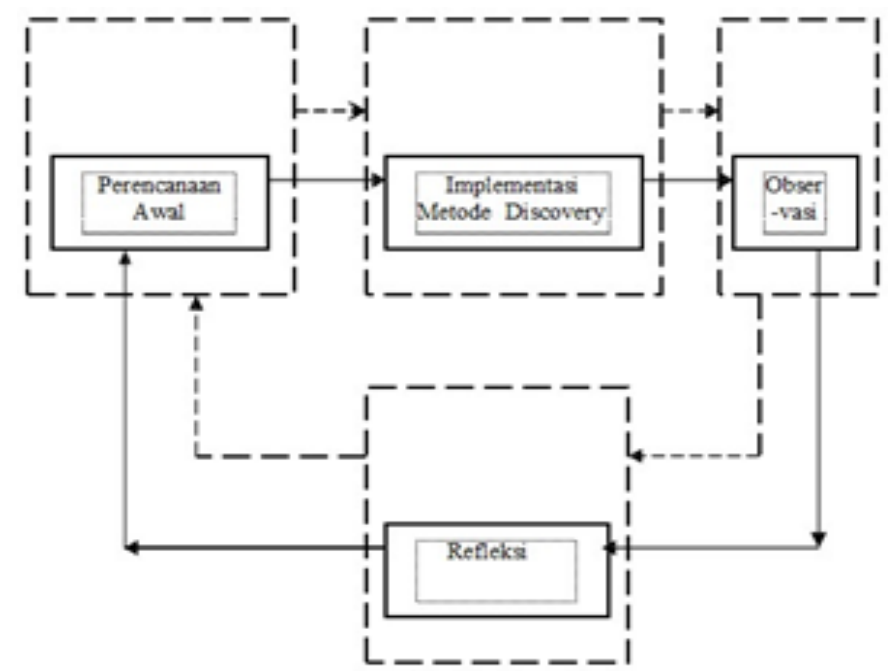

Gambar 1. Bagan Pelaksanaan Penelitian Tindakan Kelas

(Sumber bagan: Rahayu, 2005)

Prosedur sebagaimana dijelaskan pada daur PTK di atas, ditindaklanjuti dengan kegiatan-kegiatan sebagai berikut: (1) Perencanaan: Pada tahap ini akan dilakukan penyiapan Rencana Pelaksanaan Pembelajaran (RPP) yang sesuai dengan KI dan KD; Membuat lembar observasi siswa untuk mengamati aktivitas siswa dan guru; dan Menyusun soal evaluasi akhir siklus dari kegiatan pembelajaran. (2) Pelaksanaan: Melaksanakan tindakan sesuai dengan skenario yang telah direncanakan guru; Mengorientasikan siswa pada materi; Mengorganisasikan siswa untuk belajar; Membimbing siswa dalam penemuan; Mempresentasikan hasil diskusi siswa. Guru juga memberi ulasan dan penegasan terhadap jawaban presentasi siswa. Pada akhir pembelajaran melakukan membimbing siswa untuk membuat rangkuman dan mengadakan evaluasi hasil belajar. (3) Observasi:Observasi digunakan untuk mengumpulkan data tentang partisipasi siswa selama proses pembelajaran, baik diskusi dalam kelompok maupun berpendapat saat presentasi berlangsung. Observasi yang dilakukan meliputi pengamatan terhadap aktivitas siswa dan kinerja guru selamapembelajaran menggunakan model pendekatan kontekstual/Contextual Approach. (4) Refleksi. Tahap ini dilakukan untuk mengevaluasi seluruh tindakan yang dilakukan berdasarkan hasil pengamatan, berdasarkan data yang terkumpul, kemudian dilakukan evaluasi guna menyempurnakan tindakan berikutnya.

Sesuatu yang diperlukan untuk memecahkan masalah dalam penelitian adalah data yang relevan dengan permasalahannya, sedangkan untuk mendapatkan data tersebut perlu digunakan teknik pengumpulan data sehingga dapat diperoleh data yang benar-benar valid dan dapat dipercaya. Teknik pengumpulan data yang digunakan dalam penelitian ini, antara lain: a) Data tentang aktivitas siswa dalam pembelajaran diambil dari lembar observasi untuk siswa. b) Data tentang proses belajar mengajar pada saat dilaksanakannya tindakan diambil dari lembar observasi untuk guru, c) Data hasil belajar diperoleh dari hasil tes evaluasi akhir siklus. Adapun kategori penilaian sebagai berikut:

Tabel 1. Kriteria Kategori Penilaian Prestasi Belajar

\begin{tabular}{cc}
\hline Rentang & Kategori \\
\hline $76 \%-100 \%$ & Baik \\
\hline $51 \%-75 \%$ & Cukup \\
\hline $26 \%-50 \%$ & Kurang \\
\hline $0 \%-25 \%$ & Tidak \\
\hline
\end{tabular}


Data observasi aktivitas siswa selama proses pembelajaran menggunakan kriteria sebagai berikut:

Tabel 2. Kriteria Penilaian Observasi Siswa

\begin{tabular}{llcl}
\hline No & Kriteria Aspek & Rentang Skor & Keterangan \\
\hline 1 & Sangat Baik & $10-12$ & Tuntas \\
\hline 2 & Baik & $7-9$ & Tuntas \\
\hline 3 & Cukup & $4-6$ & Belum Tuntas \\
\hline 4 & Kurang & $0-3$ & Belum Tuntas
\end{tabular}

\section{HASIL DAN PEMBAHASAN}

II.

Deskripsi Hasil Penelitian mencakup kondisi awal, tindakan siklus I dan tindakan siklus

\section{Kondisi Awal}

Hasil penelitian pada sesi test awal yang bertujuan melihat peta kompetensi guru dalam hal pelaksanaan penilaian dapat dilihat dalam sajian tabel sebagai berikut.

Tabel 3. Hasil Tes Formatif Kondisi Awal

\begin{tabular}{llcc}
\hline \hline \multirow{2}{*}{ No } & \multirow{2}{*}{ Kriteria } & \multicolumn{2}{c}{ Kondisi Awal } \\
\cline { 3 - 4 } & & Jumlah & \% \\
\hline 1 & Tuntas & 16 & 50,00 \\
\hline 2 & Belum Tuntas & 16 & 50,00 \\
\hline \multirow{2}{*}{ Jumlah } & $\mathbf{3 2}$ & $\mathbf{1 0 0 , 0 0}$ \\
\hline \multirow{2}{*}{ Nilai Rata - rata } & & $\mathbf{6 6 , 2 5}$ \\
\hline
\end{tabular}

Tabel di atas menunjukan bahwa dari 32 siswa yang dikenai tindakan 16 orang siswa $(50,00 \%)$ dinyatakan tuntas, sedangkan 16 orang siswa $(50,00 \%)$ dinyatakan belum tuntas. Nilai rata-rata kelas sebesar 66,25 Dari penjelasan di atas maka dapat disimpulkan bahwa proses pembelajaran memerlukan tindakan perbaikan yang akan dilaksanakan dengan pelaksanaan penelitian tindakan kelas pada siklus berikut ini. Adapun penjelasan mengenai hasil observasi terhadap aktivitas siswa selama mengikuti kegiatan pembelajaran yang dinilai menggunakan 7 indikator yaitu 1) Siswa membaca materi yang akan dipelajari. 2) Siswa berdiskusi dengan teman. 3) Siswa bertanya pada guru atau teman. 4) Siswa menyimak penjelasan dari guru. 5) Siswa membuat catatan tentang materi pelajaran. 6) Siswa menanggapi pendapat teman atau guru. 7) Siswa mengerjakan tes dengan kemampuan sendiri sebagaimana dijelaskan pada tabel berikut ini.

Tabel 4. Rekapitulasi Hasil Observasi Peningkatan Keterampilan Siswa dalam Kegiatan Pembelajaran pada Kondisi Awal

\begin{tabular}{clc}
\hline \hline No & \multicolumn{1}{c}{ Uraian } & Jumlah \\
1 & Siswa Tuntas & 14 \\
2 & Persentase Tuntas & 43,75 \\
3 & Siswa Belum Tuntas & 18 \\
\hline
\end{tabular}



4 Persentase Belum Tuntas
56,25
5 Ketuntasan Klasikal
43,75

Berdasarkan tabel di atas, menunjukkan bahwa siswa yang dinyatakan tuntas sebanyak 14 siswa atau $43,75 \%$ dan sisanya sebanyak 18 siswa atau 56,25\% dinyatakan belum tuntas. Dari hasil pengamatan kondisi awal siswa terhadap pembelajaran bahasa Inggris serta berbagai hambatan-hambatan yang muncul. Peneliti memperoleh gambaran bahwa pada saat pembelajaran dimulai siswa ramai dan tidak peduli terutama dalam diskusi kelompok, siswa malu bertanya dan kurang menanggapi pendapat teman atau guru. Maka peneliti melakukan kolaborasi untuk mengatasi hambatan dan kesulitan yang ditemukan bersama observer, menyusun dan melaksanakan serangkaian perencanaan tindakan guna mengatasi hambatanhambatan tersebut, yang diakhiri pada sebuah kegiatan analisis atau refleksi.

\section{Siklus I}

Pembelajaran siklus I dilaksanakan selama dua kali pertemuan disesuaikan dengan rencana pembelajaran yang telah dirumuskan sebelumnya. Pelaksanaan tindakan penelitian kelas ini menekankan pada penerapan pendekatan kotekstualuntuk meningkatkanketerampilan dan prestasi belajar siswa. Pada pelaksanaan pendekatan kotekstual dibuat kelompokkelompok. Siswa diberikan kebebasan untuk mengemukakan pendapat, berdiskusi, bertanya kepada teman satu timnya, untuk menyelesaikan suatu masalah yang kemudian hasilnya dipresentasikan di depan kelas oleh perwakilan tim dan indikator proses pembelajaran.Pada siklus I ini dalam tahap pelaksanaan sudah menunjukkan adanya peningkatan prestasi belajar siswa. Hal tersebut dapat dilihat pada tabel berikut ini.

Tabel 5. Rekapitulasi Nilai Tes Formatif Pembelajaran pada Siklus I

\begin{tabular}{llcc}
\hline \hline No & Kriteria & \multicolumn{3}{c}{ Kondisi Awal } \\
& & Jumlah & \% \\
1 & Tuntas & 26 & 81,25 \\
2 & Belum Tuntas & 6 & 18,75 \\
& Jumlah & $\mathbf{3 2}$ & $\mathbf{1 0 0 , 0 0}$ \\
& Rata - rata & $\mathbf{7 2 , 5 0}$ & \\
\hline
\end{tabular}

Dari tabel di atas dapat diterangkan bahwa nilai rata-rata prestasi belajar pada pelaksanaan perbaikan pembelajaran siklus I sebesar 72,50 jumlah siswa yang tuntas belajarnya sebanyak 26 siswa atau sebesar $81,25 \%$, dan jumlah siswa yang belum tuntas belajarnya sebanyak 6 siswa atau sebesar $18,75 \%$. Dari penjelasan di atas maka dapat disimpulkan bahwa proses pembelajaran memerlukan tindakan perbaikan yang akan dilaksanakan dengan pelaksanaan penelitian tindakan kelas karena ketuntasan belajar baru mencapai angka 81,25\% atau 25 orang siswa dari batasan minimal $85 \%$ dari jumlah siswa dinyatakan tuntas belajarnya dan nilai hasil belajar secara klasikal hanya mencapai angka 72,50 dari batasan minimal 75,00. Penjelasasan hasil observasi keterampilan siswa pada pelaksanaan perbaikan pembelajaran pada siklus I sebagaimana tabel di bawah ini.

Tabel 6. Rekapitulasi Hasil Observasi Peningkatan Aktivitas Siswa dalam Kegiatan Pembelajaran pada Siklus I

\begin{tabular}{|c|c|c|}
\hline No & Uraian & Jumlah \\
\hline 1 & Siswa Tuntas & 25 \\
\hline 2 & Persentase Tuntas & 78,13 \\
\hline
\end{tabular}


3 Siswa Belum Tuntas

4

Persentase Belum Tuntas

$5 \quad$ Ketuntasan Klasikal

\section{7}

21,87

$\mathbf{7 8 , 1 3}$

Dari tabel di atas, dapat disimpulkan bahwa dari 32 siswa terdapat 25 orang yang tuntas belajarnya $(78,13 \%)$ dilihat dari keterampilan belajarnya, sedangkan 7 siswa $(21,87 \%)$ belum tuntas dilihat dari keterampilan belajarnya. Melihat hasil di atas maka peneliti bersama-sama dengan observer sepakat untuk melaksanakan perbaikan pembelajaran pada siklus II dengan harapan pada siklus II keterampilan belajar siswadapat mencapai perolehan di atas $85 \%$ sesuai dengan kriteria keberhasilan yang telah ditetapkan.

Berdasarkan hasil observasi untuk guru siklus I, dari 16 aspek yang diamati diperoleh 7 aspek bernilai A (sangat baik), 7 aspek bernilai B (baik), 1 aspek bernilai C (cukup) dan 1 aspek bernilai D (kurang) sebagaimana terangkum dalam tabel berikut.

\section{Tabel 7. Rekapitulasi Hasil Observasi Aktivitas Guru dalam Kegiatan Pembelajaran} pada Siklus I

\begin{tabular}{|c|c|c|c|}
\hline No & Nilai & Jumlah & Prosentase \\
\hline 1 & $\begin{array}{l}\text { A (Amat } \\
\text { Baik) }\end{array}$ & 7 & 43,75 \\
\hline 2 & B (Baik) & 7 & 43,75 \\
\hline 3 & C (Cukup) & 1 & 6,25 \\
\hline \multirow[t]{2}{*}{4} & D (Kurang) & 1 & 6,25 \\
\hline & Jumlah & 16 & 100 \\
\hline
\end{tabular}

Berdasarkan hasil observasi yang dilakukan ketika pembelajaran siklus I tindakan kedua, maka dapat dideskripsikan bahwa proses pembelajaran berlangsung dengan lancar, pada tindakan kedua interaksi antara siswa dengan guru lebih terjalin. Berdasarkan hasil observasi dua kali pertemuan pada siklus pertama oleh observer dan penilaian hasil tes formatif siklus pertama, menunjukkan bahwa proses perbaikan pembelajaran belum memenuhi kriteria ketuntasan belajar yang diinginkan. Berdasarkan hasil diskusi dengan teman sejawat, maka kelemahan pada siklus pertama akan diatasi dengan melaksanakan kegiatan pada siklus II

\section{Siklus II}

Adapun tindakan siklus II dilakasanakan dengan 2 kali pertemuan. Berdasarkan hasil refleksi dan pengamatan pada siklus I, peneliti melakukan revisi terhadap Rencana Perbaikan PembelajaranSkenario dan langkah-langkah yang akan ditempuh oleh guru dan siswa pada saat melaksanakan kegiatan perbaikan pembelajaran, seperti pada siklus II, hanya saja dalam kegiatan inti lebih mengupayakan siswa yang belum tuntas belajar pada siklus kedua agar menempuh proses belajar lebih baik dan berhasil mencapai batas tuntas belajar yang diharapkan.

Pada siklus II ini dalam tahap pelaksanaan sudah menunjukkan adanya peningkatan hasil belajar siswa. Hal tersebut dapat dilihat pada tabel berikut ini.

Tabel 8. Rekapitulasi Nilai Tes Formatif Pembelajaran bahasa Inggris Siklus II

\begin{tabular}{cccc}
\hline \hline \multirow{2}{*}{ No } & Kriteria & Jumlah & Kondisi Awal \\
1 & Tuntas & 30 & $\%$ \\
& & 30 & 93,75 \\
\hline
\end{tabular}


2 Belum Tuntas Jumlah Nilai Rata - rata
2

32

\section{6,25}

$\mathbf{1 0 0 , 0 0}$

$\mathbf{7 8 , 1 3}$

Dari tabel di atas tentang Rekapitulasi Nilai Tes Formatif pada Siklus II dapat diterangkan bahwa nilai rata-rata prestasi belajar pada pelaksanaan perbaikan pembelajaran siklus II sebesar 78,13 jumlah siswa yang tuntas belajarnya sebanyak 30 siswa atau sebesar $93,75 \%$, dan jumlah siswa yang belum tuntas belajarnya sebanyak 2 siswa atau 6,25\%. Dari penjelasan sebagaimana tersebut dapat disimpulkan bahwa semua kriteria keberhasilan telah tercapai pada siklus kedua, dimana ketuntasan belajar mencapai angka 93,75\% sehingga telah melebihi ketuntasan minimal sebanyal 85\%. Rata-rata prestasi belajar juga sudah memenuhi KKM sebesar 75 karena pada siklus kedua nilai rata-rata mencapai angka 78,13.

Observasi dilaksanakan oleh peneliti dan observer (teman sejawat) pada saat melaksanakan kegiatan belajar mengajar.

\section{Tabel 9. Hasil Perbandingan Setiap Siklus}

\begin{tabular}{llccccc}
\hline \multirow{2}{*}{ No } & Siklus & \multirow{2}{*}{ Nilai } & \multicolumn{4}{c}{ Ketuntasan } \\
\cline { 3 - 7 } & & Tuntas & $\%$ & $\begin{array}{c}\text { Belum } \\
\text { Tuntas }\end{array}$ & $\%$ \\
\hline 1 & Awal & 66,25 & 15 & 50 & 16 & 50 \\
\hline 2 & Siklus I & 72,50 & 25 & 81,25 & 6 & 18,75 \\
\hline 3 & Siklus II & 78,13 & 28 & 93,75 & 2 & 6,25
\end{tabular}

Hasil observasi menunjukkan bahwa: Keterampilan siswa meningkat cukup baik dalam mengikuti pembelajaran dibandingkan dengan siklus I; Siswa terbiasa berkelompok, sehingga aktivitas siswa di luar kegiatan pembelajaran hampir tidak ada; Tumbuhnya sikap kritis siswa yang semakin baik dikarenakan pemahaman terhadap materi yang meningkat;

Berdasarkan deskripsi pelaksanaan tindakan pembelajaran siklus II, maka refleksi hasil perlaksanaan pada siklus II dapat dinyatakan bahwa proses pembelajaran dinyatakan berhasil karena dari hasil yang dicapai pada proses perbaikan pembelajaran siklus kedua ini, semuanya telah memenuhi kriteria ketuntasan sehingga proses pelaksanaan perbaikan pembelajaran dinyatakan tuntas pada siklus kedua dan kepada siswa yang belum tuntas akan diberikan program.

Hasil penelitian di atas selaras dengan hasil penelitian yang dilakukan oleh Sugata (2013) yang menyatakan bahwa pembelajaran kontekstual dan Pendekatan pembelajaran dapat meningkatkan prestasi siswa dalam bahasa Inggris kemampuan berbicara, dan minat siswa pada bahasa memainkan peran penting pada keberhasilan dalam mempelajari bahasa.

\section{KESIMPULAN}

Dari hasil penelitian tindakan kelas pada proses pembelajaran dengan Pendekatan kontekstual (Contextual Approach)dengan judul"Upaya Peningkatan Keterampilan dan Prestasi Belajar Siswa Melalui Pembelajaran Contextual Approach Pada Pelajaran Bahasa Inggris di SMAN 2 Kota Jambi”dapat dilaksanakan dalam proses pembelajaran,terbukti efektif meningkatkan proses pembelajaran bahasa Inggris siswa. Prestasi siswa setelah menerapkan pendekatan kontekstual(Contextual Approach)menunjukan adanya peningkatan. Hal ini terbukti dari hasil tes formatif dan observasi secara individu dari tiap siklus. Peningkatan Prestasi belajar pada studi awal sebesar 66,25, pada siklus I nilai rata-rata yang diperoleh siswa adalah 72,50 dan pada siklus II rata-rata nilai yang diperoleh siswa adalah 78,13 dengan ketuntasan belajar dari 16 siswa atau 50,00\% meningkat menjadi 26 siswa atau 81,25\% dan 93,75\% atau 30 siswa pada siklus terakhir. Keterampilan siswa dalam kegiatan diskusi dengan 
menerapkan pendekatan kontekstual meningkat dari kondisi awal sebanyak 14 siswa atau 43,75 meningkat menjadi 25 siswa atau 78,13\% dan 100\% pada siklus kedua atau 32 siswa.

\section{DAFTAR PUSTAKA}

Ardiyanto, D. S. (2013). Pembelajaran matematika dengan pendekatan kontekstual berbantuan hands on problem solving untuk meningkatkan rasa ingin tahu dan prestasi belajar siswa. Prosiding Universitas Yogyakarta, 175-184.

Fajar, F. (2014). PENERAPAN PENDEKATAN KONTEKSTUAL UNTUK MENINGKATKAN PENGUASAAN PENGGUNAAN KOSAKATA BAHASA INGGRIS. Jurnal Nalar Pendidikan, 2(2).

Fatimah, A. T., \& Zakiah, N. E. (2018). Kelancaran prosedural matematis dalam pemecahan masalah konteks pemasaran. Mathline: Jurnal Matematika dan Pendidikan Matematika, 3(2), 141-150.

Hidayat, M. S. (2012). Pendekatan Kontekstual Dalam Pembelajaran. INSANIA: Jurnal Pemikiran Alternatif Kependidikan, 17(2).

Lahir, S., Ma'ruf, M. H., \& Tho'in, M. (2017). Peningkatan prestasi belajar melalui model pembelajaran yang tepat pada sekolah dasar sampai perguruan tinggi. Jurnal Ilmiah Edunomika, 1(01).

Nurhadi, B. Y., \& Senduk, A. G. (2004). Pembelajaran kontekstual dan penerapannya dalam KBK. Malang: Universitas Negeri Malang Pres.

Parhan, M., \& Sutedja, B. (2019). Penerapan Pendekatan Pembelajaran Kontekstual Dalam Pendidikan Agama Islam di Universitas Pendidikan Indonesia. TARBAWY: Indonesian Journal of Islamic Education, 6(2), 114-126.

Silver, E. A. (1997). Fostering creativity through instruction rich in mathematical problem solving and problem posing. $Z d m, 29(3), 75-80$.

Suarjana, I. M., Riastini, N. P. N., \& Pustika, I. G. N. Y. (2017). Penerapan pendekatan kontekstual berbantuan media konkret untuk meningkatkan aktivitas dan hasil belajar. International Journal of Elementary Education, 1(2), 103-114.

Suastika, I. K., \& Rahmawati, A. (2019). Pengembangan modul pembelajaran matematika dengan pendekatan kontekstual. Jurnal Pendidikan Matematika Indonesia, 4(2), 60.

Sugata, I. N. (2013). Pengaruh Implementasi Pendekatan Kontekstual Terhadap Kemampuan Berbicara Bahasa Inggris Ditinjau dari Minat Bahasa Inggris Siswa SMK Negeri 3 Denpasar. Widyasrama, 21(1).

Sukra, I. N. (2016). PENERAPAN PENDEKATAN PEMBELAJARAN KONTEKSTUAL UNTUK MENINGKATKAN HASIL BELAJAR BAHASA INGGRIS PERHOTELAN. JEPUN: Jurnal Pendidikan Universitas Dhyana Pura, 1(2).

Wahyuningtyas, D. T., \& Suastika, I. K. (2017). Developing of Numbers Learning Module for Primary School Students Bycontextual Teaching and Learning Approach. JPDI (Jurnal Pendidikan Dasar Indonesia), 1(2), 33-36.

Zakiah, N. E., Sunaryo, Y., \& Amam, A. (2019). Implementasi pendekatan kontekstual pada model pembelajaran berbasis masalah berdasarkan langkah-langkah polya. Teorema: Teori dan Riset Matematika, 4(2), 111-120.

(2017). Pembelajaran dengan pendekatan kontekstual berbasis gaya kognitif untuk meningkatkan kemampuan metakognitif siswa. Pedagogy: Jurnal Pendidikan Matematika, 2(2).

Zulela, M. S. (2014). Pendekatan kontekstual dalam pembelajaran menulis di sekolah dasar (Action research di kelas tinggi sekolah dasar). Mimbar Sekolah Dasar, 1(1), 83-91. 